\title{
A CIRANDA DO TEMPO NA LAVOURA ARCAICA, DE RADUAN NASSAR
}

\author{
Regina Céli Alves da Silva (UniverCidade) \\ reginaceli2011@gmail.com
}

No romance Lavoura Arcaica, de Raduan Nassar, a leitura dos elementos narrativos, tais como, espaço, tempo, narrador, linguagem, mostra-se bastante reveladora, permitindo uma análise consistente da obra. Assim, a partir da observação de tais aspectos, construímos, em nossa Dissertação de mestrado, a compreensão do romance em questão.

Neste artigo, voltaremos o foco para a categoria temporal no texto de Nassar. O título da narrativa, nesse sentido, já é bastante revelador, pois inscreve no sintagma "lavoura arcaica" as dimensões de espaço e tempo para a qual está voltado.

Portanto, mais do que observar um aspecto óbvio nas construções ficcionais, isto é, o investimento temporal que as perpassa, chamamos a atenção para o fato de esse investimento ser de suma importância para o estudo da obra citada. Antes, porém, de iniciarmos as reflexões sobre o tempo, torna-se necessário um brevíssimo resumo do romance, sem o qual, talvez, nossas incursões fiquem prejudicadas.

A história é narrada, em primeira pessoa, por André, personagem principal da trama. Ele é o filho pródigo, aquele que retorna a casa, pelas mãos do irmão mais velho, que o encontra e implora por sua volta. A partir desse reencontro com Pedro, André inicia o retorno, tanto através da memória, relembrando os acontecimentos que o marcaram enquanto ainda vivia na casa dos pais, quanto pela experiência da chegada ao lar, agora com uma visão mais apurada. Os pais e os outros irmãos, especialmente Ana, com quem tem (ou quer ter) uma relação incestuosa, e Lula, o irmão mais novo, ficam satisfeitos em revê-lo. 


\section{FACULDADE DE FORMAÇÃO DE PROFESSORES}

De antemão, percebemos que a exposição das ocorrências na obra está sujeita ao crivo da memória de André, e, portanto, está condicionada ao seu singular olhar, à sua percepção. Isso é reafirmado pela voz narrativa, na passagem em que diz: "....as coisas deixam de ser vida na corrente do dia a dia para ser vida na corrente da memória” (NASSAR, 1982, p. 86).

Assim, nesse movimento de volta às origens, à casa do pai, o narrador parte numa volta circular e onde se lê a partida se lê também o retorno, e vice-versa. O presente reencontra o passado e este retorna ao presente, pois "para onde estamos indo" (NASSAR, 1982, p. 30), pergunta-se André, "estamos indo sempre para a casa", (Idem, ibidem), ele mesmo responde.

Não é à toa, por conseguinte, que o texto esteja dividido em duas partes, "A partida" e "O retorno". Na primeira, "A partida", ocorre uma evocação no tempo, da época em que André, ainda vivendo em uma pensão interiorana, recebe a visita do irmão. A chegada de Pedro aciona no narrador a partida/retorno ao passado, na memória/imaginação, quando ainda vivia na fazenda do pai.

André, voltando os olhos para o passado, entrelaça tempos, misturando-os em fatos, lembranças, sonhos, e interpretando livremente os fios lançados no solo narrativo, buscando a si próprio nas tramas temporais.

Ocorre no romance um investimento na subjetividade, A experiência interior do indivíduo, já inscrita no discurso em primeira pessoa, é reafirmada em toda a construção do corpo literário. Dessa forma, a compreensão do tempo, passando pelo filtro interno do narrador, abre possibilidades muito amplas de leitura, liberando o solo textual da linearidade da cronologia oficial.

O olhar narrativo, afetado pela vivência do presente, volta ao passado, assimilando-o por um novo prisma no qual pode rever o que foi e o que poderia ter sido. Modifica-se, pela narrativa do presente, o texto daquilo que passou, pois a reflexão atual de André leva-o a redescobrir em si mesmo dimensões que lhe foram (re)veladas com o grifo social, garantindo, até sua partida, a obediência às regras da casa do pai.

Por isso mesmo, as palavras do pai vêm à tona no discurso do narrador, expondo as raízes que lhe fundamentaram a conduta desde a infância.

O tempo é o maior tesouro de que um homem pode dispor; embora inconsumível, o tempo é o nosso melhor alimento; se medida que o conheça, o tempo é contudo nosso bem de maior grandeza; não tem começo, não tem fim; [...] (NASSAR, 1982, p. 45) 
[...] em tudo ele nos atende, mas as dores da nossa vontade só chegarão ao santo alívio seguindo esta lei inexorável: a obediência absoluta à soberania incontestável do tempo, não se erguendo jamais o gesto neste culto raro; é através da paciência que nos purificamos, em águas mansas é que devemos nos banhar [...] (Ibidem, p. 50)

[...] a paciência é a virtude das virtudes, não é sábio quem se desespera, é insensato quem não se submete. (Ibidem, p. 53)

Ao cultuar a paciência como a grande virtude, o pai concebe o homem como paciente de sua própria história, de modo que o tempo vivido se estreita numa eterna espera. Incapacitado de atuar, só resta ao indivíduo receber pacientemente o fruto plantado por outros, passando-os adiante, para compor um ciclo, sempre igual, "sem começo nem fim" (Ibidem, p. 45).

As palavras do pai, no decorrer do relato de André, estarão sempre voltadas para esse tipo de atitude paciente, imóvel, não aberta às mudanças. Mas como a vida não é só uma espera, às palavras do pai juntarse-ão as do filho, ampliando e revendo o entendimento do tempo e de sua passagem.

O tempo é versátil, o tempo faz diabruras [...]. (Ibidem, p. 82)

[...] porque existe o tempo de aguardar e o tempo de ser ágil (Ibidem, p. 84)

[...] o tempo, o tempo, esse algoz às vezes suave, às vezes mais terrível, demônio absoluto conferindo qualidade a todas as coisas, é ele ainda hoje e sempre quem decide e por isso a quem me curvo cheio de medo e erguido em suspense me perguntando qual o momento preciso da transposição? Que instante, que instante terrível é esse que marca o salto? Que massa de vento, que fundo de espaço concorrem para levar ao limite? (Ibidem, p. 85-6)

A versatilidade do tempo assinalada no discurso do narrador aponta para a visão mais ampla, e mais fecunda, da passagem temporal. E, mesmo reconhecendo a soberania do tempo sobre a vida, pois o entende como um algoz, suave e terrível, também o sente como um demônio capaz de fazer diabruras, imprimindo no homem uma competência.

Tal competência o narrador demonstrou, ao agir sobre seu próprio percurso existencial, partindo da casa do pai, abandonando a segurança dos seus limites e das palavras paternas, para encontrar seu verbo singular, ainda que para isso tivesse que se expor às diversas ações do tempo: a chuva, o sol, o frio, a fome. Por isso, mesmo identificando em sua história os fundamentos originários do mito do filho pródigo bíblico, André amplia as dimensões do mito, renovando-o, porque ao se apropriar da 


\section{FACULDADE DE FORMAÇÃO DE PROFESSORES}

história mítica, incorpora-a ao seu domínio particular, transgredindo códigos culturais que, até então, eram de domínio coletivo.

É na história do filho pródigo, refeita com requintes proporcionados pela capacidade de reflexão do narrador, que vamos encontrar a escritura do romance, percebendo nele o trabalho múltiplo, diversificado e pessoal, não só com o tempo, mas também com todas as outras dimensões que participam da armação literária.

A parábola bíblica conta a história do filho pródigo, que deixa a casa paterna levando sua parte nos bens da família e, após andança pelo mundo, retorna à casa do pai que, para comemorar, festeja com a carne de um bezerro, vinho e dança a chegada do filho.

O texto bíblico põe em evidência suas características dogmáticas, formativas, construindo, pela representação simbólica do filho pródigo, uma fábula que vai além da simples partida e retorno do filho a casa, revelando um conteúdo no qual a paciência e a comiseração do patriarca são virtudes ressaltadas nas mãos de quem retém o poder, pois acolher aquele que retorna, que no excesso de suas ações rebelou-se contra o pai, significa recuperar com "magnificente bondade" a ordem onde esta havia sido quebrada.

Encontra-se, ainda, na parábola bíblica, um reforço a respeito do retorno à origem e à repetição eterna e circular das lições do pai/Pai. Essa circularidade faz aparecer outro mito, o do eterno retorno. Mas, como bem o compreende André, a passagem do tempo produz marcas e o indivíduo, envolvido no processo histórico, na dinâmica dos acontecimentos, se depara, a todo o momento, com novos rumos, novos projetos, mesmo que venham revestidos em suas velhas roupagens.

Assim, por exemplo, o século XX revistou a tradicional fonte bíblica através do texto escrito pelo autor francês André Gide. Intitulada "A volta do filho pródigo", a narrativa gideana aborda a parábola original, desfazendo, no entanto, a ideia das repetições eternas e iguais. Nessa obra, Gide faz um acréscimo humano, aumentando o número de personagens, inserindo a mãe, o irmão caçula e um filho pródigo que, ao retornar, não vem resignado e humilde, mas marcado pela diferença de quem viu o mundo, conheceu outras pessoas, outros lugares, alargando suas fronteiras, seus limites.

Tanto a escritura francesa quanto a Lavoura arcaica, de Nassar, fazem mais do que relatar a volta ao lar do filho resignado e submisso. 
Ambas investem no questionamento, na não aceitação gratuita da submissão, pois, afinal, o mundo e suas relações já não são mais os mesmos.

Em Lavoura arcaica, uma grande diferença se estabelece já na primeira linha da narrativa, uma vez que, de forma oposta à parábola bíblica, a história é narrada pelo próprio filho pródigo. Ou seja: ele conta o que viu, sentiu, aprendeu. Não há outra pessoa manipulando sua pessoal versão dos fatos. Lendo sua história, participamos, junto a ele, dos desejos, sentimentos, emoções, fantasias, enfim, de tudo o que compôs a sua fuga.

Compreendemos, portanto, que, se André se identifica com a mítica figura do filho pródigo, é porque percebe que, diante das situações capazes de gerar algum tipo de mudança, que não se sabe aonde vai dar, é muito mais fácil apostar nas conhecidas fórmulas, no retorno de antigos equilíbrios. Mas ele se coloca em outro lado, aquele de quem simplesmente não olhou o frio ou a fome de outra pessoa, mas de quem os sentiu no próprio corpo.

A preocupação de André em registrar, em contraponto com as palavras do pai, esse lado do discurso, o verso e o reverso da moeda, fica bem clara, por exemplo, quando ele relembra a Pedro que o pai, sentado à cabeceira da mesa, na hora das refeições, com toda a família a sua volta, costumava contar a história de um faminto.

É a história de um homem que, estando com muita fome e passando diante de um palácio, resolve parar e pedir uma refeição aos guardiões do local. Como resposta, ouve que o amo, o dono do palácio seria o único capaz de oferecer-lhe tudo de que necessitava. Uma vez na presença do senhor, um ancião de barbas brancas, explica-lhe sua difícil situação e o homem, compadecido, concorda em lhe dar comida e bebida à vontade.

Mas, o que o faminto pensava ser o fim de sua fome, pareceu-lhe, ao contrário, uma tortura, pois o ancião, em vez de mandar servir comida de verdade, mandou trazer, para testar a paciência e o caráter do outro, um grande banquete fictício, isto é, não havia o que comer, tudo não passava de encenação.

Diante da cena, o necessitado não se dá por vencido e entra no jogo, elogiando as iguarias, os vinhos, fingindo, inclusive, estar embriagado, pois, pensa consigo mesmo: "os pobres devem ter muita paciência di- 
ante dos caprichos dos poderosos, abstendo-se por isso de mostrar irritação" (NASSAR, 1982, p. 69).

Finalmente, estando o rico satisfeito com o que presenciara, afinal havia encontrado um homem com o "espírito forte" (Idem, ibidem, p. 73), o caráter firme, e, sobretudo, que "revelou possuir a maior das virtudes de que um homem é capaz: a paciência" (Idem, ibidem, p. 53), resolve então convidar o faminto a morar em sua casa, prometendo-lhe que nunca mais passaria fome ou sede. Logo em seguida, manda servir um pão robusto e verdadeiro.

Terminando de narrar e lembrar a Pedro a velha história que o pai tantas vezes contara nos seus sermões, ao redor da mesa de refeições, André pergunta ao irmão:

Como podia o homem que tem o pão na mesa, o sal para salgar, a carne e o vinho, contar a história de um faminto? Como podia o pai, Pedro, ter omitido tanto nas tantas vezes que contou aquela história oriental? (Ibidem, p. 53)

E, então, André narra para o irmão uma das cenas omitidas pelo pai; aquela em que, fingindo-se embriagado com o vinho fictício, e antes mesmo de receber o elogio por sua paciência, o faminto, com a força de sua fome, surpreende o anfitrião, aplicando-lhe violento murro. Mas logo trata de esclarecer o incidente, proclamando-se extremamente agradecido pela bondade do outro, satisfeitíssimo com o banquete e com o vinho, que, no entanto, subira-lhe à cabeça, levando-o a desfechar o soco contra o benfeitor.

Esse outro lado da história é, com certeza, muito menos interessante para todos os que detêm o poder, sendo, por isso mesmo, omitido em nome da conservação da ordem e de posturas de subserviência e aceitação.

No entanto, André, que durante muito tempo em sua vida, conhecera apenas a versão do pai, o lado dos que sempre comeram os frutos plantados por outros, agora podia, conhecendo novas versões das histórias, o lado dos famintos, por exemplo, reconhecer a si próprio como uma face diferente na história da família.

Não é por acaso que ele, reexaminado a parábola do filho pródigo, reconduz sua memória ao contexto religioso que tanto influenciou sua vida desde pequeno. Mas, ironicamente, o menino que teve os dogmas religiosos da tradição judaico-cristã como suportes e argumentos em sua educação, no decorrer do tempo, se vê envolvido no mais transgressivo 
dos comportamentos, a relação incestuosa que deseja manter com sua irmã Ana.

E é essa manifestação incestuosa da sexualidade que abre em sua vida a impossibilidade maior de reconduzi-lo, mesmo que quisesse, ao retorno igual, a um reequilíbrio dentro do código tradicional de sua família. Em suas palavras, "era Ana a minha enfermidade, ela a minha loucura, ela o meu respiro, a minha lâmina, meu arrepio, meu sopro, o assédio impertinente dos meus testículos" (NASSAR, 1982, p. 94).

A enfermidade, a loucura, o sopro, enfim, a reunião de manifestações tão diversas em seu amor pela irmã, conjuga-se, porém, no discurso de seu corpo, contaminando-o e levando-o a ultrapassar, com sua prodigalidade, conteúdos normativos.

$\mathrm{Na}$ divisão entre a sua fé e seu lado objetivamente carnal, André reúne os pedaços que o constituem como ser humano completo e inicia o aprendizado de si próprio, para tentar enxergar quem ele é na realidade e na história da família.

O retorno no tempo em busca de sua narrativa existencial revela que sua história tem atrás de si muitas outras histórias, como a parábola do filho pródigo, eternamente gravado na escritura bíblica. Mas o aprendizado acontece quando percebe que o seu não é mais um texto compilado.

A experiência pessoal narrada pelo filho pródigo de Lavoura arcaica reconduz a trama romanesca de modo que ela não mais traduza os anseios e necessidades de pessoas que não a viveram (como acontece com o texto bíblico). Ao contrário, faz com que seja uma versão singular, um registro diferente de quem quer escrever sua história como um profeta, mas "não aquele que alça os olhos para o alto, antes o profeta que tomba o olhar com segurança sobre o s frutos da terra" (Idem, ibidem, p. 76).

Repetir as palavras do pai, dos velhos textos, não caracterizou a narrativa como uma cópia alienada do ato de viver projetado por outros, mas como resultado do exercício pleno da vontade de conhecer, transformado na compreensão de que a sabedoria está em aprender a conjugar os diversos tempos com a devida reverência a cada um deles, sem que um não anule o outro.

A escritura do texto constitui o grande lucro de André, porque, ao fazê-lo, ele se capacitou, na medida em que, olhando para frente e para trás, reinterpretou sua trajetória de vida, para abrir o diálogo entre o que 


\section{FACULDADE DE FORMAÇÃO DE PROFESSORES}

foi e o que é, remexendo o solo cultural e familiar em busca de suas raízes, sem medo de enxergá-las.

Sendo assim, André faz com o seu texto aquilo que o agricultor zeloso faz com a sua terra: utiliza as ferramentas com amor e carinho para lavrar seu campo, nutrindo-o com os implementos necessários ao crescimento da vegetação e fazendo-a florescer e frutificar, não como uma fala desvinculada do todo cultural, mas sim, como uma palavra respeitada em sua diferença.

\section{REFERÊNCIAS BIBLIOGRÁFICAS}

A PARÁBOLA do filho pródigo. In: Bíblia sagrada. Novo testamento. São Paulo: Edigraf, 1961. T. 4. Lucas, c. 15: 11-32.

GIDE, André. A volta do filho pródigo. Trad. Ivo Barroso. Rio de Janeiro: Nova fronteira, 1984.

MENDILOW, A. A. O tempo e o romance. Trad. Flávio Wolf. Porto Alegre: Globo, 1972.

NUNES, B. O tempo na narrativa. São Paulo: Ática, 1988.

POUILlON, J. O tempo no romance. Trad. Heloysa de Lima Dantas. São Paulo: Cultrix, 1974.

NASSAR, Raduan. Lavoura arcaica. 2. ed. Rio de Janeiro: Nova Fronteira, 1982.

TODOROV, T. As estruturas narrativas. São Paulo: Perspectiva, 1979. 